\title{
Two new species of Chironomidae collected in winter on the shore of Lake Biwa, Honshu, Japan
}

\author{
Manabu SASA ${ }^{1)}$ and Machiko Nishino ${ }^{2)}$ \\ ${ }^{1)}$ Sasa Institute of Hygiene, 984-37, Tetsugami, Kurobe, 938 Japan \\ 2) Lake Biwa Research Institute, 1-10, Uchidehama, Otsu, 520 Japan
}

(Received: 21 May 1996; Accepted: 29 July 1996)

Key words: Chironomidae, non-biting midges, Biwatendipes biwamosaicus, Hydrobaenus biwagrandis, new species, Lake Biwa, Biwatendipes, Hydrobaenus

\begin{abstract}
Daytime collections of adult chironomids resting on the shore and those floating on the water surface were carried out on February 8,1995 , on a day in the coldest winter season of a year under the atmospheric temperature of about $8^{\circ} \mathrm{C}$. A total of 76 adult male specimens were collected, and 60 among them were Biwatendipes motoharui Tokunaga, 3 were Biwatendipes biwamosaicus sp. nov., 5 were Hydrobaenus biwaquartus Sasa et Kawai, 1 was Hydrobaenus biwagrandis sp. nov., 1 was Orthocladius biwaniger Sasa et Kawai, 3 were Smittia aterrima (Meigen), 3 were Smittia nudipennis (Goetghebuer). The new species Biwatendipes biwamosaicus sp. nov. is quite unusual in the structure, the apical scales of tibiae and the hypopygium of males are characteristic of Biwatendipes, but the structure of head is similar to that of females, and wings are extremely wide.
\end{abstract}

\section{INTRODUCTION}

Lake Biwa is the largest lake in Japan, situated in the middle of Shiga Prefecture in central Honshu, and has a surface area of $674 \mathrm{~km}^{2}$. It is composed of the North Basin of $616 \mathrm{~km}^{2}$ with the maximum depth of $103.6 \mathrm{~m}$, and the South Basin of $58 \mathrm{~km}^{2}$ with the maximum depth of $5 \mathrm{~m}$, and both are connected with a channel of about $1.5 \mathrm{~km}$ in width. This lake is known to be very rich in the indigenous animal species, and extensive collections of the chironomid specimens found on the shore of this lake were carried out by Sasa and Kawai (1987), five times in different seasons during the period of April 1985 to June 1986, and a total of 71 species of the family Chironomidae, including 6 new species and 5 species new to Japan, were previously recorded. Later, Sasa and Ni- shino (1995) collected adult chironomids on the shore of this lake at Otsu City on March 1, 1995, and recorded Biwatendipes motoharui Tokunaga, 1965, Hydrobaenus biwaquartus (Sasa et Kawai, 1987), and two new species, Orthocladius biwainfirmus Sasa et Nishino, 1995 and Orthocladius biwaniger Sasa et Nishino, 1995.

The present survey was carried out on February 8, 1995, and adult chironomids were collected with insect net or sucking tubes on the shore of three sites at the side of the South Basin and two sites at the North Basin. As the results, a total of 76 adult males including two new species belonging to the genus Biwatendipes and Hydrobaenus could be identified.

The specimens of the adult chironomid midges used in the present study were all preserved first in $70 \%$ alcohol, and later mounted on slides in gumchloral solution after digested in hot $10 \%$ potassium hy- 
droxide solution and dissected with the methods described by Sasa (1989).

\section{Biwatendipes biwamosaicus sp. nov.} (Fig. 1)

Holotype: No. 264: 78. Paratypes: No. 264: 79, 80. Type locality and collection data: Three males were collected while floating on the water of Lake Biwa at Mizuga-hama on February 8,1995 . The holotype and paratype specimens are deposited in Sasa Institute of Hygiene, Kurobe, Japan.

Male. BL 3.61, 3.78, $3.69 \mathrm{~mm}$, WL 1.66, $1.61,1.64 \mathrm{~mm}, \mathrm{WW} / \mathrm{WL} 0.42,0.40,0.41$ (very wide). Ground color of scutum and scutellum yellow. Scutal stripes brown. Postnotum dark brown. Legs largely yellow but tips of femora and bases and tips of tibiae dark brown. Abdominal tergites I to VI largely brownish yellow and with yellow bands along oral and caudal margins, VII with an U-shaped brown area along oral and lateral margins. Hypopygium largely dark brown.

Head in Fig. 1a. Eyes bare, reniform and without dorsomedial extension, ER 1.48, $1.54,1.37$ (very high). Antennae with only 6 flagellar segments each bearing only 4-6 short setae and look quite the same as that of female (female antennae of $B$. motoharui are composed of 5 segments). Palp also very short, segments I to IV nearly globular, $\mathrm{P} / \mathrm{H} 0.59,0.64,0.64$ (all very short). $\mathrm{SO}$ 0 or $1, \mathrm{CL} 8,14,8$. Antepronotum (Fig. 1b) widely separated in the middle, without seta. Distribution of setae on scutum and scutellum in Fig. 1c; scutum without median, lateral and prealar setae (quite unusual character). Scutellar setae 4, 4, 6 .

Wings very wide, membrane bare (a character peculiar to this genus), venation in Fig. 1d. Squama bare. Cross vein $\mathrm{R}-\mathrm{M}$ nearly parallel to wing axis (a characteristic of Tanytarsini). RR 0.59, 0.61, 0.69, VR $1.24,1.23,1.21, \mathrm{R} / \mathrm{Cu} 1.09,1.07,1.08$. Tips of all tibiae (Fig. 1e, f, g) with a simple and pointed terminal scale, without comb scales (characteristic to Biwatendipes).
Tarsi I to $\mathrm{V}$ of front legs (Fig. 1h) are relatively long and narrow, as in other Tanytarsini species, but those of middle and hind legs (Fig. $1 \mathrm{i}, \mathrm{j}$ ) are all very short and wide. Tarsi IV of middle and hind legs cordiform, tarsi $\mathrm{V}$ with a small pulvilli, an empodium, and claws (Fig. 1k).

Setae on abdominal tergites relatively small, the distribution as in Fig. $1 \mathrm{~m}, 14$ on I, 10 on II, 16 on III to V, 22 on VI and VII, 24 on VIII, and 14 on IX in the holotype. Hypopygium in Fig. 1n. Ninth tergite with a small and ventrally hooked anal point (Fig. 1p, lateral view). Dorsal appendage (Fig. 1q, dorsal view, left and right; Fig. 1r, ventral view with digitus) elongate oval, with 4 setae on dorsal side, and a small apically hooked digitus on ventral side. Median appendage (Fig. 1s) short, bearing many curved and slightly foliate setae. Ventral appendage (Fig. 1s) short, stout, apically rounded, with 14 short and straight setae on distal portion. Gonostylus (Fig. $1 \mathrm{~m}$ ) stout, with numerous short setae, inner margin slightly concave.

Remarks. These specimens were considered, at first, belonging to a family other than Chironomidae, but after detailed studies of its structure now considered as a member of Biwatendipes Tokunaga, 1964, with unusual structure of female-like head. It is similar to $B$. motoharui Tokunaga, 1964, in all tibiae with a simple pointed terminal scale and without terminal combs. The structures of anal point and median and ventral appendages of male hypopygium are quite similar to those of $B$. motoharui, and wings are unusually wide but venation is basically of the Tanytarsini-type. The female of $B$. motoharui as described by Sasa and Kawai (1987) is similar to the present specimens so far as the head is examined, but in the latter, antennae are 5 segmented, wings much narrower, and the hypopygium is entirely different, composed mainly of spermathecae and cerci. It is also quite characteristic that scutum has no dorsal setae in this new species. 


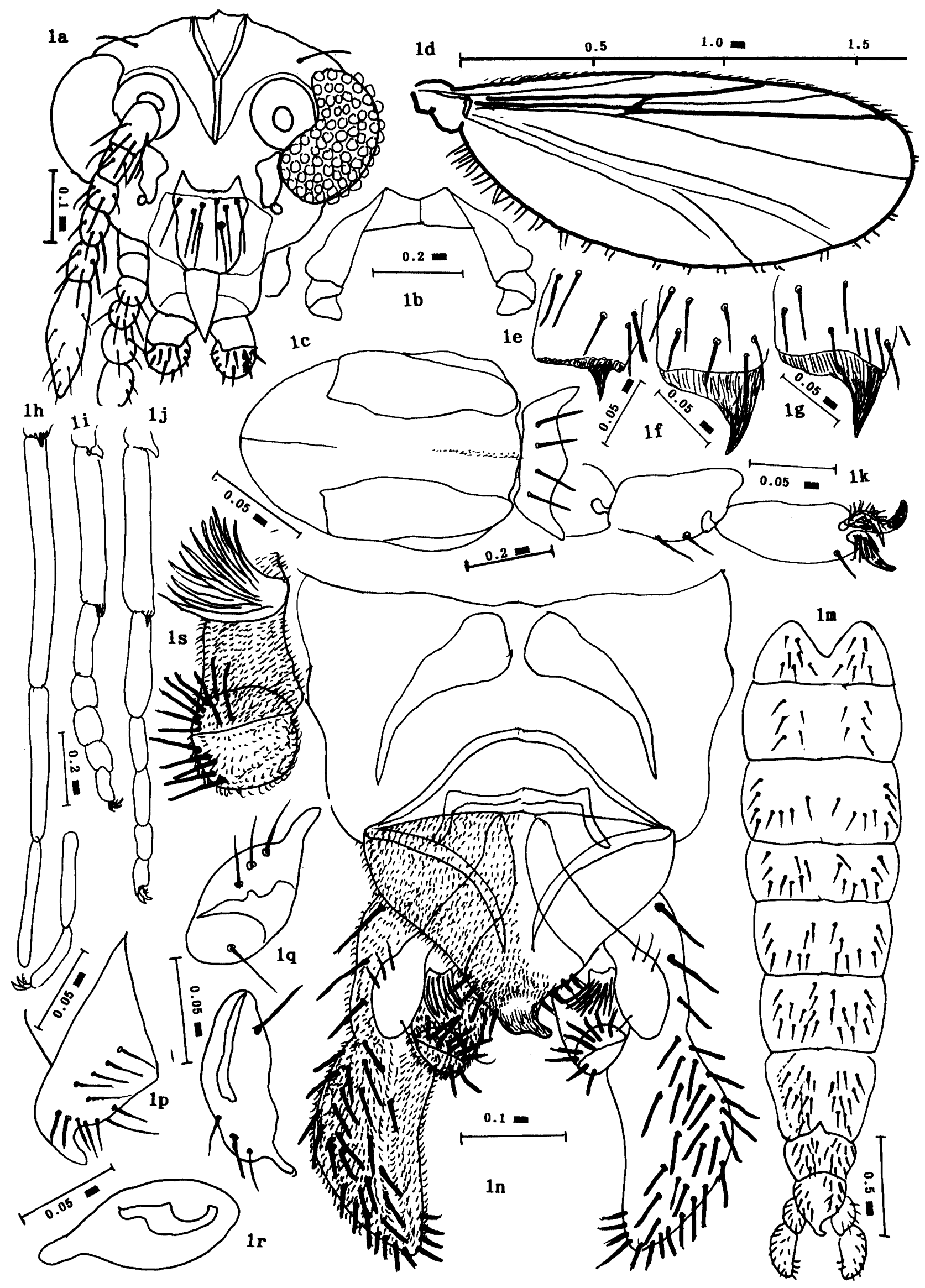

Fig. 1. Biwatendipes biwamosaicus sp. nov. 
Hydrobaenus biwagrandis sp. nov. (Fig. 2)

Holotype: No. 264: 69. Type locality and collection data: one male was collected on the shore of Lake Biwa at Shina on February 8,1995 . The holotype specimen is deposited in Sasa Institute of Hygiene, Kurobe, Japan.

Male. BL $6.46 \mathrm{~mm}$, WL $3.86 \mathrm{~mm}$ (both very large), WW/WL 0.27 (narrow). Body almost entirely black, scutum with a pair of large humeral pale areas (Fig. 2c). Head in Fig. 2a. Eyes with a long and narrow dorsomedial extension, ER 0.54. Antenna composed of 13 flagellar segments, AR 3.33 (very high). Palp long, $\mathrm{P} / \mathrm{H} 1.42$, the first segment nearly globular but the second segment much longer than wide, 2.7 times as long as wide. SO 24:24 (very many) in a single row. CL 36 (very many). Antepronotum (Fig. 2b) united in the middle, with 24:24 lateral setae (very many). Distribution of setae on scutum and scutellum in Fig. 2c; DM 0, DL 9:9, PA $6: 6$, SC 10 (all very small).

Wings bare, smooth, venation of the Orthocladius type, as in Fig. 2d. Costa slightly extended beyond tip of $\mathrm{R}_{4+5}$, which is distal to tip of $\mathrm{Cu}_{1}, \mathrm{R} / \mathrm{Cu} 1.10 . \mathrm{R}_{2+3}$ ending closer to tip of $R_{1}$ than to tip of $R_{4+5}, R R$ 0.43. FCu distal to $\mathrm{R}-\mathrm{M}, \mathrm{VR}$ 1.09. $\mathrm{Cu}_{2}$ nearly straight. Squama with 86:88 fringe hairs (very many). Anal lobe strongly produced inwards. Tip of front tibia (Fig. 2e) with a long spur, $124 \mu$ long and 1.7 times as long as the diameter of front tibia at the tip. Tip of middle tibia (Fig. 2f) with two short spurs, 29 and $48 \mu$ long. Tip of hind tibia (Fig. $2 \mathrm{~g}$ ) with one long spur $(93 \mu$ long), but without the short spur present in most other Orthocladiinae species, and with a terminal comb composed of 14 free spurs. Tips of tarsi I and II of middle and hind legs each with two short subterminal spurs. Tarsi IV cylindrical and longer than tarsi $V$. Pulvilli absent.

Setae on abdominal tergites (Fig. $2 \mathrm{~h}$ ) are very many, 180 on tergite I, 160 on tergite II, 136 on III, 120 on IV, 128 on V and VI, distributed more densely on lateral portions. Hypopygium in Fig. 2i. Ninth tergite obtusely angulate posterior margin, with 12 long setae in the lateral portion, and 24 short setae on posterior margin, anal point absent. Small virga composed of several codes seems to be present, but the detailed structure is not discernible due to the darkness of the tergite. Gonocoxite with a rectangular inner lobe in the basal $1 / 3$ (Fig. 2j). Gonostylus stout, widest at about middle, without preapical tooth and with a strong megaseta.

Remarks. The genus Hydrobaenus in the sense of Sasa and Kikuchi (1995, p. 61, 164) includes certain species formerly described as members of Eukiefferiella and Tokunagaia from Japan, and a total of 20 species have so far been recorded from Japan. According to the key (Sasa and Kikuchi, 1995), it runs to $H$. togaundecimus (Sasa et Okazawa, 1992), in the following characteristics: anal point is absent, dorsolateral setae of scutum is strong, dorsomedian setae of scutum is absent, and gonocoxite with inner lobe (single in the present species and double in $H$. togaundecimus). However, the body coloration is almost entirely black in the present species (largely yellow and with brown marks on scutum and postnotum in $H$. togaundecimus), WL is $3.86 \mathrm{~mm}$ and much larger than $1.85-1.90 \mathrm{~mm}$ of the latter, ER is 0.54 and much smaller than 1.06-1.10 of the latter, $\mathrm{AR}$ is 3.33 and much larger than 1.29-1.38 of the latter, palps are very long and $\mathrm{P} / \mathrm{H}$ is $1.42(0.89-0.90$ in the latter $)$. Furthermore, the numbers of setae on head and antepronotum are SO $24: 24$, CL 36 , and $\mathrm{PN} 24: 24$, and are much larger in the present species (SO 12-14, CL 12, PN 4 in the latter), while those on scutum are DM 0, DL 9:9, PA 6:6, SC 10 and not much different from DM 0, DL 8-10, PA 45 , SC $15-18$ of the latter. The structures of inner lobes of gonocoxite and of gonostylus are also quite different between the two species, as shown in Sasa and Oka- 


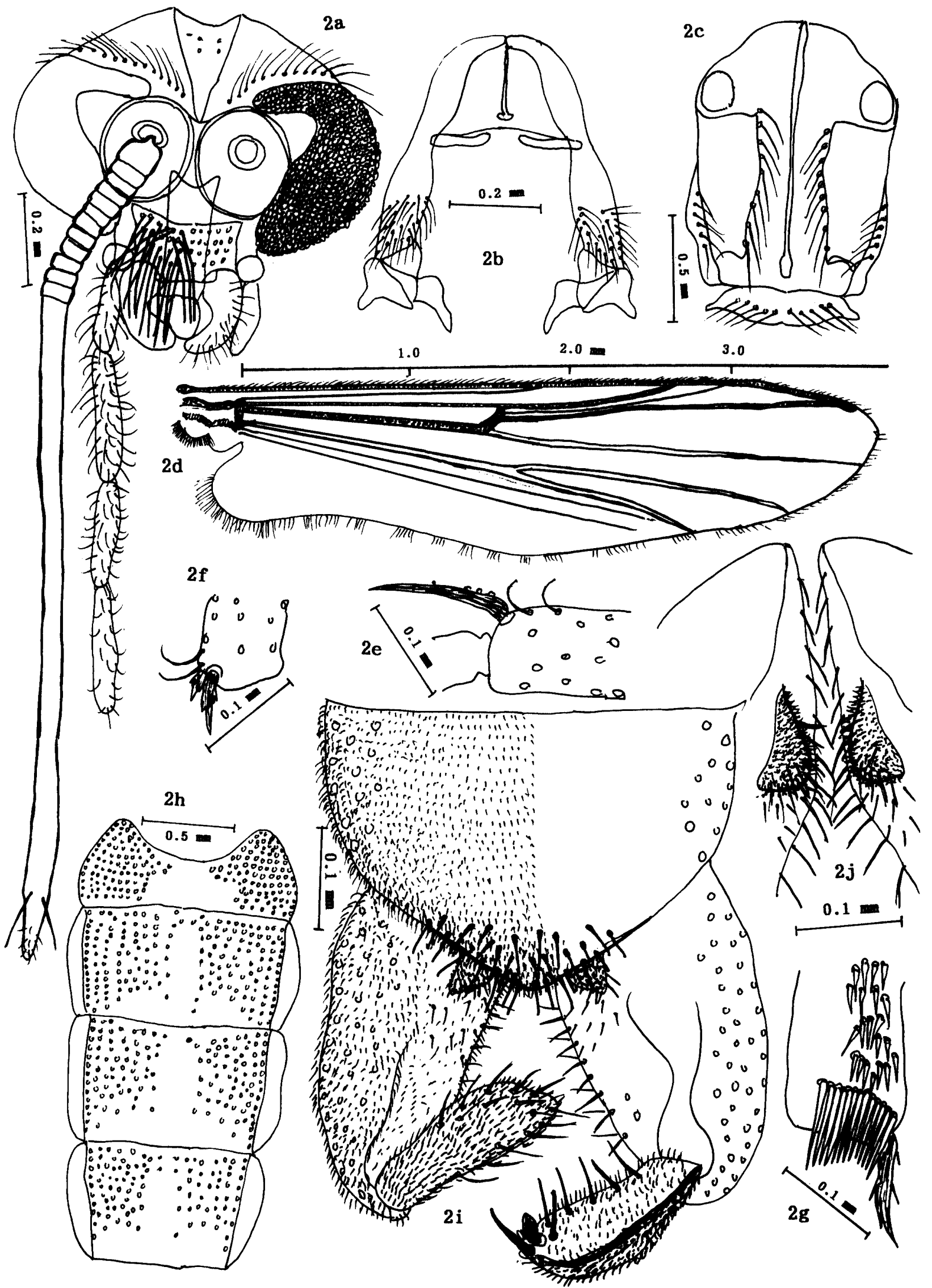

Fig. 2. Hydrobaenus biwagrandis sp. nov. 
zawa (1992, Fig. 26) for the latter species.

\section{ACKNOWLEDGEMENTS}

Thanks are due to Mrs. Izumi Watanabe, who prepared the slide mounted speciems used in the present study.

\section{REFERENCES}

Sasa, M. (1989) Chironomidae of Japan: checklist of species recorded, key to males, and taxonomic notes. Sci. Rep. Natl. Inst. Environ. Stud., R-125, 1142.

Sasa, M. and K. Kawai (1987) Studies on the chironomid midges of Lake Biwa. Lake Biwa Study Monographs. (3), 1-119. Lake Biwa Research Institute.

Sasa, M. and M. Kikuchi (1995) Chironomidae of Japan. 333 pp., University of Tokyo Press, Tokyo.

Sasa, M. and M. Nishino (1995) Notes on the chironomids collected in winter on the shore of Lake Biwa. Jpn. J. Sanit. Zool., 46: 1-8.

Sasa, M. and T. Okazawa (1992) Studies on the chironomid midges of Toga-mura, Toyama. Pt 2. The subfamily Orthocladiinae. Res. Rep. Toyama Environ. Res. Center, 1992: 205-231.

Tokunaga, M. (1965) A new snow midge from Japan. Kontya, 33: 42-45.

\section{摘 要}

琵琶湖岸で冬期に採集されたユスリカ科の 2 新種

$$
\begin{aligned}
& \text { 佐々 学 }{ }^{11} \text { 西野麻知子 }{ }^{21} \\
& \text { （テ938 黒部市鉄上 984-37） } \\
& { }^{21} \text { 滋賀県琵琶湖研究所 } \\
& \text { （宁520 大津市打出浜） }
\end{aligned}
$$

琵琶湖に発生するユスリカ科 Chironomidae の昆虫 については既に佐々，河合 (1987) の年間にわたる調查, および佐々，西野 (1995) の冬期における調查が報告さ れているが，今回は年間において最も寒い時期における 1995 年 2 月 8 日の昼間に琵琶湖の南湖の岸 2 力所と北 湖の岸 3 力所で, 捕虫網と吸虫管を用いユスリカの成虫 を採集し, かつ湖岸の水面に浮かんでいる成虫, 蛹を拾 いあげて，ガムクローラル封入標本として同定を行っ た. 合計して 76 個体の雄標本が得られ, それらは Biwatendipes motoharui Tokunaga が60, Hydrobaenus biwaquartus Sasa et Kawai が 5, Orthocladius biwaniger Sasa et Kawai が 1, Smittia aterrima (Meigen) が 3, Smittia nudipennis (Goetghebuer) が 3 の既知種に加えて, 今回 Biwatendipes biwamosaicus sp. nov. と命名した雄が 3 個体, および Hydrobaenus biwagrandis sp. nov. と命名した雄が 1 個体であった。 ここに両新種の雄の記載を行った．前者は八ネや脚の構 造は Biwatendipes 属の特徽に一致するが, 触角の構造 はユスリカの倠のそれに似た極めて特異な形態を示し， かつ八ネが異常に幅広い，後者は日本産の本属のうち特 にH. togaundecimus (Sasa et Okazawa) に近い形態を 示しているが，それょり体がはるかに大きく，ARや $\mathrm{P} / \mathrm{H}$ の值が大で, SO, CL, PN, などの毛の数も 2 倍以上, かつ生殖器の形態にも差があって, 明らかに別種とみな される. 